\title{
NANOPARTICULATE ZIRCONIA-MODIFIED SOLID SOLUTIONS OF ALUMINUM-IRON OXIDES FOR POLISHING TITANIUM METAL
}

\author{
L. F. Koroleva ${ }^{1 *}$ \\ ${ }^{1}$ Institute of Engineering Science, Ural Branch of the Russian Academy of Sciences, 34 Komsomolskaya st., \\ Ekaterinburg, Russian Federation \\ "Corresponding author. E-mail: 1q@imach.uran.ru; address for correspondence: ul. Komsomolskaya 34, 620049, \\ Ekaterinburg, Russian Federation. Tel.: +7 (343) 374-18-53; fax: +7 (343) 374-53-30
}

A synthesis mechanism of nanoparticulate zirconia-modified $\mathrm{Al}_{2-x} \mathrm{Fe}_{x} \mathrm{O}_{3}$ solid solutions has been studied with the application of X-ray diffraction, IR spectroscopy, DTA, particle-size analysis and chemical analysis. The solid solutions have been prepared via heat treatment of ammonium hydroxycarbonate complexes. The nanoparticles are shown to consist of crystalline rhombohedral $\alpha-\mathrm{Al}_{2-x} \mathrm{Fe}_{x} \mathrm{O}_{3}$, monoclinic and tetragonal $\left(\mathrm{M}-\mathrm{ZrO}_{2}\right.$ and $\left.\mathrm{T}-\mathrm{ZrO}_{2}\right)$. The synthesized mixed oxide offers a high polishing ability ( 3 to 4.5 times as high), as demonstrated in polishing of titanium, and ensures surface roughness values $R_{a}$ ranging between 0.019 and $0.009 \mu \mathrm{m}$.

Keywords: aluminum-iron oxides, zirconia, X-Ray diffraction, polishing, titanium, nanoroughened surface.

\section{Introduction}

For the development of precision engineering and electronics, it is necessary to obtain the surface of various metals and non-metals with minimum roughness $R_{a}$, for example, less than $0.005 \mu \mathrm{m}$. For this purpose, surface processing is applied, with the last stage being final polishing with the use of abrasive nanodispersed materials, such as natural and synthetic nanodiamond powders, boron or silicon carbides, cubic boron nitride and ultradispersed powders based on aluminum oxide (corundum) and silicon dioxide with a granularity ranging between 0.01 to 0.3 and 6 to $10 \mu \mathrm{m}[1-10]$.

When ultradispersed nanodiamonds, corundums, silicon carbides, boron carbides or nitrides are used, i.e. abrasive materials with high hardness, polishing is primarily a mechanical process of roughness microcutting and relief smoothing. It should be taken into consideration that the polishing process is long and multistage. Final polishing is usually performed 3 to 5 times, with a consistent reduction in the grit of abrasive slurries used in preliminary operations, finishing and fine finishing.

The mechanical polishing process is a complex interaction among the material being processed, the pad and the abrasive particles. Exploring the mechanism of polishing of different metals with nanodispersed abrasives, one cannot but state that it is governed by a mechanical impact on the surface with the formation of new solid phases at the interface, that is, with a chemical process. According to many authors, productive abrasive materials for final polishing of metals include medium hardness abrasives based on transition metal oxides or their solid solutions [11-15].

For final polishing, promising is the development of the synthesis of nanodispersed tribochemical active abrasive materials on the basis of solid solutions of transition element oxides. The application of nanodispersed tribochemical active abrasive materials based on solid solutions of aluminum-iron oxides with the crystal structure of corundum and hematite reduces the number of finishing operations of polishing with the view of obtaining a nano-roughened surface as a result of changing from mechanical polishing to mechanical-chemical polishing. As a result of the use of these materials, a nano-roughened surface is achieved for hardened solid steels, non-ferrous metals (particularly, aluminum) and their alloys [16, 17]. 
A challenge is to produce a nano-roughened surface of titanium and its alloys. The most widely used methods include electrochemical polishing of titanium. However, the achieved surface roughness is $R_{a}-0.250 .20 \mu \mathrm{m}$ [18].

The mirror surface of pure titanium and titanium alloys, with $\mathrm{R}_{\mathrm{a}}$ less than $0.1 \mu \mathrm{m}$, is known to be achievable by using abrasive $\mathrm{Al}_{2} \mathrm{O}_{3}$ grains for intensive mechanical polishing, the contact pressure being 0.1 and $0.4 \mathrm{MPa}$ [19].

The ratio between the microhardness of the material being polished and that of the abrasive material is significant in the processes of polishing. Thus, the microhardness $H v$ of titanium is $1800 \mathrm{MPa}$. For mechanical-chemical polishing to be feasible, i.e. with chemical reactions in the near-surface layer, the ratio between the microhardness of the material to be polished and that of the abrasive material must not exceed 1.8. Therefore the use of complex oxides of aluminum and iron, with the hardness $H v$ of 1650 to $1700 \mathrm{MPa}$, was proposed for polishing titanium and its alloys [20].

Various techniques of fabricating nanosized particles of powders based on aluminum oxide are known, for instance, synthesis by pulse heating, hydroxide sol-gel deposition with subsequent thermal treatment, self-propagating high-temperature synthesis (SHS), or mechanical-chemical methods [21-26].

However, complex aluminum-iron oxides are less effective for final polishing of such materials as titanium and its alloys. Polishability can be increased by modifying complex aluminum-iron oxides with, e.g., zirconium oxides. It has long been recognized that the polymorphism of zirconium oxide can be tuned by doping with $\mathrm{Y}^{3+}, \mathrm{Yb}^{3+}, \mathrm{Ca}^{2+}, \mathrm{Ce}^{4+}$, etc., yttrium (III) being widely used as a stabilizer of the tetragonal phase. The monoclinic phase was retained when yttrium oleate was added in the ripening stage of monoclinic $\mathrm{ZrO}_{2}$. Therefore ion doping must occur during the $\mathrm{ZrO}_{2}$ nucleation and growth stages [27-32].

Promising is a solid phase method for synthesizing solid aluminum-iron solutions obtained by heat treatment of hydroxy-complexes like $\mathrm{M}^{2+}{ }_{1-\mathrm{x}} \mathrm{M}^{3+}{ }_{\mathrm{x}}(\mathrm{OH})_{2}\left(\mathrm{X}^{\mathrm{n}-}\right)_{\mathrm{x} / \mathrm{n}} \bullet \mathrm{mH}_{2} \mathrm{O}$. The structure of these compounds is composed of positively charged hydroxide layers $\left[\mathrm{M}_{1-\mathrm{x}}{ }^{2+} \mathrm{M}_{\mathrm{x}}{ }^{3+}(\mathrm{OH})_{2}\right]^{\mathrm{x}^{+}}$and anions $\mathrm{X}^{\mathrm{n}-}$. The necessary bond structure is formed in the first stage, namely, the deposition and formation of hydroxy-complex. A significant advantage of this method is unrestricted variation of the atomic ratio of the elements during deposition. In total, the formation of intermediate complex compounds of hydroxycarbonates followed by thermohydrolysis yields qualitatively new functional properties.

This work studies the synthesis of zirconia-modified complex aluminum-iron oxides proposed as an abrasive material for final polishing of titanium and its alloys.

\section{Experimental Procedure}

The solid solutions of aluminum-iron oxides and those modified by zirconium dioxide were prepared by heat treatment of precipitated ammonium hydroxycarbonates at temperatures between 950 and $1150^{\circ} \mathrm{C}$. In the course of precipitation, zirconyl ions were added in the form of a $0.1 \mathrm{M}$ $\mathrm{ZrOSO}_{4}$ solution. The iron oxide concentration in the reaction product was varied in the range between 0.12 and $0.2 \mathrm{~mol} \%$, and the zirconium dioxide concentration was varied from 0.001 to $0.008 \mathrm{~mol} \%$. The content of aluminum and iron in the samples was determined by standard procedures of the X-ray fluorescence analysis with the use of an EDX-900HS energy dispersive spectrometer, with a relative statistical deviation of $\pm 0.0005 \mathrm{~mol} \%$. The contents of $\mathrm{NH}_{4}^{+}$was determined photometrically, and the contents of $\mathrm{CO}_{3}{ }^{2-}$ was determined volumetrically as follows: the samples dried at room temperature were heated to $220-250^{\circ} \mathrm{C}$, and the carbon dioxide was captured by an alkali solution [33]; the total content of the $\mathrm{OH}^{-}$and $\mathrm{CO}_{3}{ }^{2-}$ groups was determined by the oxalate method.

The following methods were applied to the examination of the samples: IR spectroscopy, with the use of a Shimadzu JR-475 spectrophotometer, the samples being pressed into tablets with $\mathrm{KBr}$; XRD analysis with a STADI-P diffractometer using a software program for comparing 
diffraction peaks with the data from JCPDS-ICDD PDF2, with $\mathrm{Cu} K \alpha_{\alpha}$ radiation (nickel filter). The step scan is $0.03^{\circ}$ and range of $2 \Theta$ was 5 to $70^{\circ}$, the counting was 5 to $25 \mathrm{~s}$ for each step.

The particle-size analysis of the samples was performed by gravity sedimentation by a Shimadzu SA-CP2 centrifugal analyzer, the viscosity of the dispersion medium being $0.0093 \mathrm{P}$ and the density of the liquid phase $1.0 \mathrm{~g} / \mathrm{cm}^{3}$, and by a scanning electron microscopy with a Tescan VEGA II XMU scanning electron microscope, $U_{a c c}=15 \mathrm{kV}$. The thermal and thermogravimetric effects in the course of heating of the samples in the $\mathrm{Al}_{2} \mathrm{O}_{3}-\mathrm{Fe}_{2} \mathrm{O}_{3}-\mathrm{ZrO}_{2}$-system were measured using complex thermal analysis on a Q-1500 derivatograph (Hungary), heating rate of 10$11^{\circ} \mathrm{C} / \mathrm{min}, 20-1000^{\circ} \mathrm{C}, 500-\mathrm{mg}$ samples.

The abrasive properties of the samples in the polishing processes were assessed by standard procedures of measuring polishability and surface roughness $\left(R_{a}\right)$ with a Wyko NT1100 optical profiler and by atomic force microscopy (AFM) with a Nanoscan scanning probe microscope working in the hard contact mode. The topography was registered as a discrete function $Z=f(x, y)$ defined on a two-dimensional array of discrete variables. In the measurement of surface roughness by scanning at maximum $9 \times 9 \mu \mathrm{m}(9.70 \mathrm{um} \times 9.32 \mathrm{um})$, with a resolution of $512 \times 512$ pixels, the scanning speed was $30 \mu \mathrm{m} / \mathrm{s}$. The AFM study of roughness is a series of shots with various surface parts. In each frame the parameters of the standard deviation of the heights were calculated. The resulting surface roughness on this scale was assessed as a value, averaged over a set of the same frame size. The value of the standard deviation of the heights of the surface topography can be calculated as follows:

$$
\sigma=\sqrt{1 / N^{2}\left[\sum_{i, j} Z_{i, j}-\bar{Z}\right]^{2}}
$$

Surface roughness $R_{a}$ is the arithmetic mean of the absolute value deviations within the profile length, and it is determined as follows:

$$
\mathrm{R}_{\mathrm{a}}=1 / \mathrm{n} \sum\left|\mathrm{y}_{\mathrm{i}}\right|
$$

The starting samples, VT1-00 titanium (99.9\% Ti), had initial surface roughness $R_{a}=1.3-$ $1.6 \mu \mathrm{m}$. In the experiment, each point was determined on five samples. The results obtained were processed by methods of mathematical statistics and the sampling was verified for the normal distribution of the results.

The polishability was determined as:

$$
\mathrm{P}=\Delta \mathrm{M} / \mathrm{S} \cdot \mathrm{t},
$$

where $\Delta M(\mathrm{mg})$ is the mean weight loss due to polishing, $S\left(\mathrm{~cm}^{2}\right)$ is the area of the polished surface and $t(\mathrm{~min})$ is the duration of polishing. The titanium cylindrical samples had the following dimensions: diameter $17 \mathrm{~mm}$, height $20 \mathrm{~mm}$.

To simulate the polishing process, a specialized unit based on a "Metapolan 2" vibration device was installed (fig. 1). The samples were placed in special cells on platform 1, covered with a cloth, where there was room for polishing paste serving as a sanding pad (2). The samples were pressed by load of 18 to $30 \mathrm{kPa}(9)$; the rotation of the samples was due to the rotation of the spindle (7) from an electric motor (4), the speed being adjusted by a resistor (5). The sample rotation rate was $89 \mathrm{rpm}$. The polishing suspension was prepared from the abrasive powder $(10 \mathrm{~g})$ and distilled water $(90 \mathrm{ml})$ with a suspension $\mathrm{pH}$ of 7-8. A woolen cloth was used as a polishing pad, with a polishing paste consisting of water and abrasive powder being applied to it every 15 minutes, as the optimal experimental time. The process was monitored against the change in the 
metal removal and the surface quality. The agglomeration of the polishing paste did not occur during the whole process of polishing.

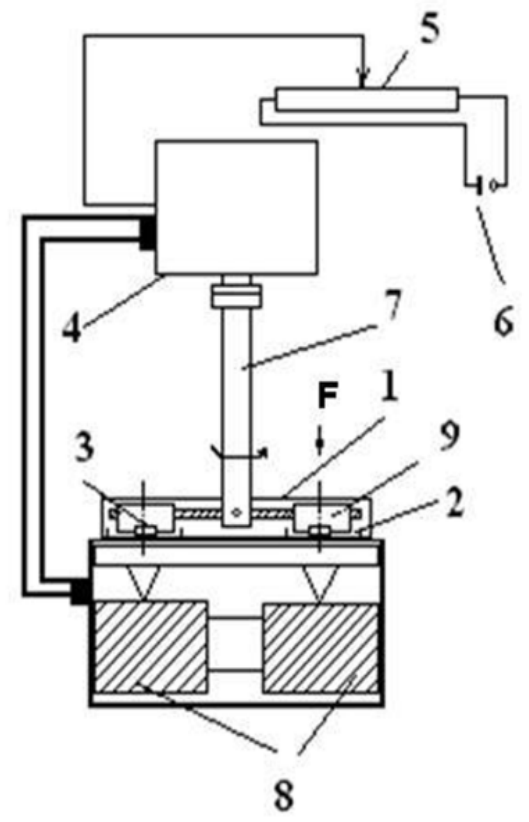

Fig. 1. Flowchart of polishing: 1 - platform; 2 - pad with slurry (polishing paste); 3 - sample; 4 electric motor; 5 - resistor; 6 - AC source; 7 - spindle; 8 - electromagnets; 9 - load.

\section{Results and Discussion}

The experimental data and IR spectroscopy have shown that the precipitated ammonium aluminum-iron hydroxycarbonates doped with zirconyl-ions contain hydroxyl and carboxyl groups. Studying the synthesized samples and their heat-treatment products at temperatures ranging between 25 and $1150^{\circ} \mathrm{C}$ by $\mathrm{XRD}$ analysis, one can represent the general formula as $\mathrm{NH}_{4} \mathrm{Al}_{2} \mathrm{Fe}(\mathrm{OH})_{5}\left(\mathrm{CO}_{3}\right)_{2} \mathrm{nH}_{2} \mathrm{O}$. When in the first stage aluminum, iron and zirconium precipitate from the sulfate solution (the results of IR spectroscopy and chemical analysis), ammonium aluminum-iron hydroxycarbonates and zirconium hydroxycarbonates are formed. These compounds are similar in the composition to the ammonium hydroxycarbonates of cobalt, aluminum and chromium previously studied earlier in [34]. The overall reaction of aluminum-iron hydroxycarbonate precipitation can be represented as follows:

$$
\mathrm{FeSO}_{4}+\mathrm{Al}_{2}\left(\mathrm{SO}_{4}\right)_{3}+9 \mathrm{NH}_{4} \mathrm{HCO}_{3}=\mathrm{NH}_{4} \mathrm{FeAl}_{2}(\mathrm{OH})_{5}\left(\mathrm{CO}_{3}\right)_{2}+4\left(\mathrm{NH}_{4}\right)_{2} \mathrm{SO}_{4}+2 \mathrm{H}_{2} \mathrm{O}+7 \mathrm{CO}_{2} \text {. }
$$

The formation of ammonium hydroxycarbonates is characterized by the stability constant $\mathrm{K}$ and determined by the equilibrium constant $\mathrm{K}=1 / \mathrm{K}_{1}$ of the decomposition of the compound $\mathrm{NH}_{4} \mathrm{FeAl}_{2}(\mathrm{OH})_{5}\left(\mathrm{CO}_{3}\right)_{2}$ :

$$
\mathrm{NH}_{4} \mathrm{FeAl}_{2}(\mathrm{OH})_{5}\left(\mathrm{CO}_{3}\right)_{2}=\mathrm{Fe}(\mathrm{OH})_{2}+2 \mathrm{Al}(\mathrm{OH}) \mathrm{CO}_{3}+\mathrm{NH}_{4} \mathrm{OH} .
$$

As in the process of decomposition iron hydroxide and aluminum hydroxycarbonate are formed, the equilibrium constant is characterized by the ammonium hydroxide dissociation constant $\mathrm{K}_{\mathrm{d}}$, and it depends on the concentration of $\mathrm{Fe}^{2+} \mathrm{Al}^{3+}, \mathrm{OH}$ and $\mathrm{CO}_{3}^{2}$. This can be represented as:

$$
\mathrm{K}_{1}=\mathrm{K}_{\mathrm{d}}\left[\mathrm { Fe } ^ { 2 + } \left[\mathrm{Al}^{3+}\left[\mathrm{OH}^{-}\right]^{4}\left[\mathrm{CO}_{3}^{2-}\right]^{2}\right.\right.
$$


where $\mathrm{K}_{\mathrm{d}}$ is the ammonium hydroxide dissociation constant equal to $1.8 \cdot 10^{-5}$. As a result of calculations, the stability constant for the complex is $0.17 \cdot 10^{5}$, i.e. the complex of hydroxycarbonates is a stable compound in the synthesis reaction.

The precipitation of zirconium from the solution can be represented by the following reaction [35]:

$$
2 \mathrm{ZrOSO}_{4}+6 \mathrm{NH}_{4} \mathrm{HCO}_{3}=\left(\mathrm{NH}_{4}\right)_{2} \mathrm{Zr}_{2} \mathrm{O}_{2}(\mathrm{OH})_{2}\left(\mathrm{CO}_{3}\right)_{2}+4 \mathrm{CO}_{2}+2 \mathrm{H}_{2} \mathrm{O}+2\left(\mathrm{NH}_{4}\right)_{2} \mathrm{SO}_{4} \text {. }
$$

From the theoretical concepts of olation in the formation of polynuclear complexes of hydroxide compounds and from the data of IR spectroscopy and chemical analysis, in view of the oxidation of $\mathrm{Fe}^{2+}$ into $\mathrm{Fe}^{3+}$, the composition of the hydroxycarbonates of ammonium, $\mathrm{Al}^{3+}$ and $\mathrm{Fe}^{2+}$ can be represented by the following scheme:

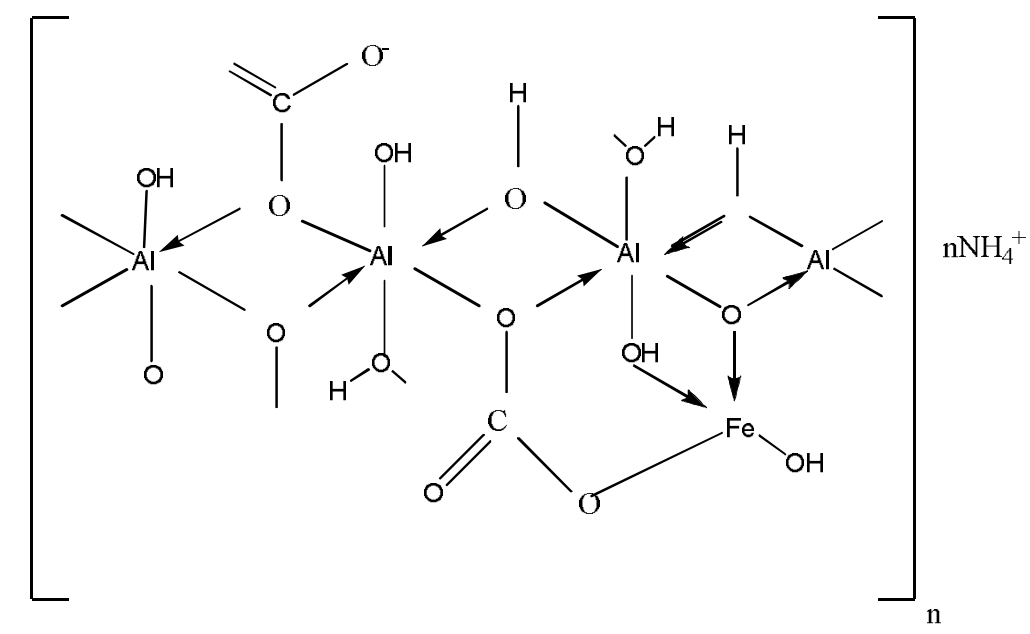

For zirconium hydroxycarbonate, the scheme is as follows:

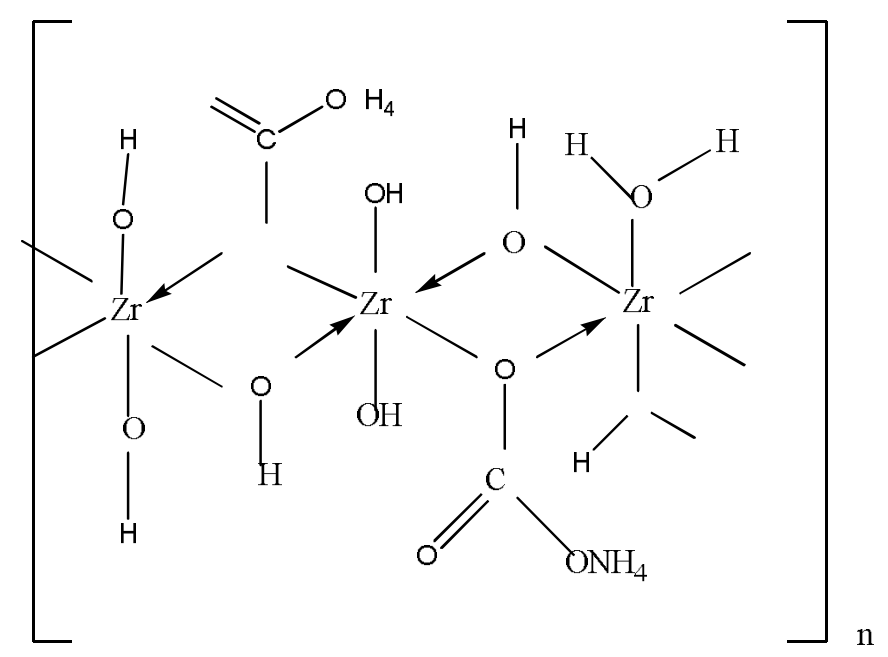

On the IR spectrums of the samples there are the following absorption bands: intense narrow bands in the region of the stretching vibrations of the $\mathrm{OH}^{-}$groups with pronounced peaks at 3200 and $3450 \mathrm{~cm}^{-1}$, which correspond to the stretching vibrations of the bond of the associated Fe-O-H and Al-O-H hydroxyl groups; the bands at 860 and $985 \mathrm{~cm}^{-1}$ are the deformation vibrations of the $\mathrm{OH}^{-}$groups; the $1100 \mathrm{~cm}^{-1}$ band is due to the deformation vibrations of $\mathrm{OH}^{-}$characteristic of the hydrogen bridge bond, and this confirms the polymeric nature of the compound. The bidentate nature of the carbonate group is confirmed by the split frequencies of degenerate vibrations $v_{1}$ with 
the symmetric states of the monodentate and bidentate groupings $\mathrm{C}_{2 v}$ and $\mathrm{C}_{\mathrm{s}}$ (absorption bands $1395 ; 1445-1449$ and $\left.1540 \mathrm{~cm}^{-1}\right)$.

At the second stage in the process of solid-phase synthesis, when hydroxycarbonates are treated at temperatures ranging between 950 and $1150^{\circ} \mathrm{C}, \mathrm{Fe}^{2+}$ is oxidized into $\mathrm{Fe}^{3+}$ and solid solutions of aluminum-iron oxides are formed, as well as zirconium dioxide, and this is supported by the data of the chemical and X-ray diffraction analyses.

The process of heat treatment of ammonium hydroxycarbonate with inclusion of zirconium dioxide can be represented as follows:

$$
\begin{gathered}
\mathrm{NH}_{4} \mathrm{Al}_{2} \mathrm{Fe}(\mathrm{OH})_{5}\left(\mathrm{CO}_{3}\right)_{2}+\left(\mathrm{NH}_{4} \mathrm{Zr}_{2} \mathrm{O}_{2}(\mathrm{OH})_{2}(\mathrm{CO} 3)_{2} \rightarrow \mathrm{Al}_{2} \mathrm{Fe}(\mathrm{OH})_{4} \mathrm{O}_{2}+\mathrm{Zr}_{2} \mathrm{O}_{2}(\mathrm{OH})_{2} \rightarrow\right. \\
\rightarrow \mathrm{Al}_{2} \mathrm{O}_{3} \cdot \mathrm{Fe}_{2} \mathrm{O}_{3 \text { amorp }}+\mathrm{ZrO}_{2 \text { amorp }} \rightarrow \mathrm{Al}_{2-\mathrm{x}} \mathrm{Fe}_{\mathrm{x}} \mathrm{O}_{3 \text { cryst }}+\mathrm{ZrO}_{2 \text { cryst }}
\end{gathered}
$$

The equations for the reaction of the decomposition of hydroxycarbonates during heat treatment are:

$$
\begin{gathered}
4 \mathrm{NH}_{4} \mathrm{FeAl}_{2}(\mathrm{OH})_{5}\left(\mathrm{CO}_{3}\right)_{2}+10 \mathrm{O}_{2}=2 \mathrm{Fe}_{2} \mathrm{O}_{3}+4 \mathrm{Al}_{2} \mathrm{O}_{3}+4 \mathrm{NH}_{3}+8 \mathrm{CO}_{2}+12 \mathrm{H}_{2} \mathrm{O} \\
\left(\mathrm{NH}_{4}\right)_{2} \mathrm{Zr}_{2} \mathrm{O}_{2}(\mathrm{OH})_{2}\left(\mathrm{CO}_{3}\right)_{2}=2 \mathrm{ZrO}_{2}+2 \mathrm{CO}_{2}+2 \mathrm{H}_{2} \mathrm{O}+2 \mathrm{NH}_{3}
\end{gathered}
$$

The formation of a solid solution of aluminum-iron oxides of a rhombohedral modification with the $R-3 c$ spatial group is confirmed as follows: $\alpha-\mathrm{Al}_{2-\mathrm{x}} \mathrm{Fe}_{\mathrm{x}} \mathrm{O}_{3}(85.9$ mass \%) - by the diffraction lines (012), (104), (110), (116), $\alpha-\mathrm{Fe}_{2} \mathrm{O}_{3}(7.7$ mass \%) - by the $h k l$ lines (012), (104), (110), (116); the formation of tetragonal zirconium dioxide (1.9 mass \%) with the $P 42 / n m c$ spatial group is corroborated by the $h \mathrm{kl}$ lines (101) (110), (112), and the presence of monoclinic $\mathrm{ZrO}_{2}(3.7$ mass \%) with the $R 21 / c$ spatial group - by the $h k l$ lines (011) (-111), (111).

In addition, orthorhombic $\mathrm{AlFeO}_{3}(3.7$ mass \%) with the Pna21 spatial group is formed ( $h k l$ lines (011), (111), (022), (122)). Figure 2 is a diffraction pattern for the samples of $\mathrm{ZrO}_{2}$-modified complex aluminum-iron oxides ( $2 a$ : the diffraction lines of tetragonal $\mathrm{ZrO}_{2}$ are marked with "o" and the diffraction lines of monoclinic $\mathrm{ZrO}_{2}$ are marked with " $\mathrm{x}$ "; $2 b$ : unmodified complex aluminumiron oxides).

The chemical $\mathrm{X}$-ray fluorescence energy-dispersive analysis shows the following composition: $70.0 \% \mathrm{Al}_{2} \mathrm{O}_{3} ; 25.0 \% \mathrm{Fe}_{2} \mathrm{O}_{3} ; 5.0 \% \mathrm{ZrO}_{2}$, this being in good agreement with the XRD data. In the study of the $\mathrm{Al}_{2} \mathrm{O}_{3}-\mathrm{ZrO}_{2}$ system under solid-phase synthesis at a temperature of 1150 to $1200^{\circ} \mathrm{C}$ it was found that rhombohedral aluminum oxide $\alpha-\mathrm{Al}_{2} \mathrm{O}_{3}$ ( $h k l$ lines (012), (104), (110), (113), (116)), tetragonal zirconium dioxide ( $h k l$ lines (101), (110), (112)) and monoclinic phase (lines $h k l(011),(-111),(111))$ are formed. $\mathrm{M}-\mathrm{ZrO}_{2}$ formation is consistent with the data found in $[36,37]$.

The chemical $\mathrm{X}$-ray fluorescence energy-dispersive analysis shows the following composition: $63.1 \% \mathrm{Al}_{2} \mathrm{O}_{3} ; 36.9 \% \mathrm{ZrO}_{2}$, this being in good agreement with the XRD data.

The data obtained from the sedimentation and electron microscopy studies demonstrate (fig. 3, $4 a, 4 b)$ that the samples of complex aluminum-iron oxides $\left(0.12\right.$ to $0.156 \mathrm{~mol} \% \mathrm{Fe}_{2} \mathrm{O}_{3}$ and 0.04-0.08 mol \% $\mathrm{ZrO}_{2}$ ) contain nanoparticles: the main fraction is particles sized $50 \mathrm{~nm}$. The samples with the concentration $0.08 \mathrm{~mol} \% \mathrm{ZrO}_{2}$ (fig. $4 b$ ) contain nanoparticles more than $50 \mathrm{~nm}$. The samples contain nanoparticles up to $10 \mathrm{~nm}$ in size, which are collected into larger particles through electrostatic attraction. But these particles quickly fall apart into small nanoparticles; therefore, in polishing, no scratches are left on the surface sample. 

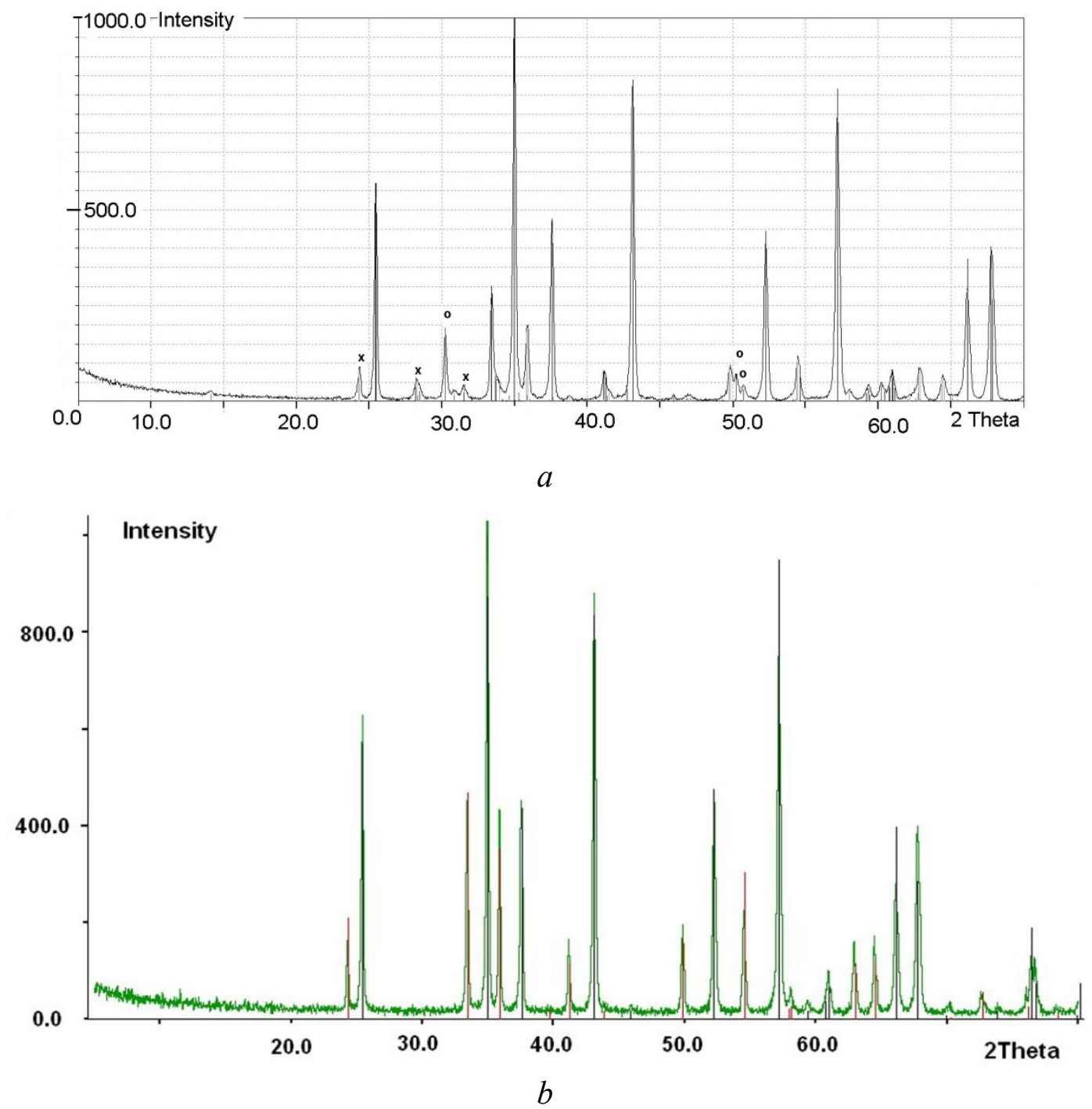

Fig. 2. XRD patterns of aluminum-iron oxide samples: $(a)$ modified with $0.004-0.008$ mol $\% \mathrm{ZrO}_{2}$ (the diffraction lines of tetragonal $\mathrm{ZrO}_{2}$ are marked with "o" and the diffraction lines of monoclinic $\mathrm{ZrO}_{2}$ are marked with " $\mathrm{x}$ "), the counting being $5 \mathrm{~s}$ for each step; $(b)$ unmodified (Miller indices for $\alpha-\mathrm{Al}_{2-x} \mathrm{Fe}_{x} \mathrm{O}_{3}$ ), the counting being $25 \mathrm{~s}$ for each step. 


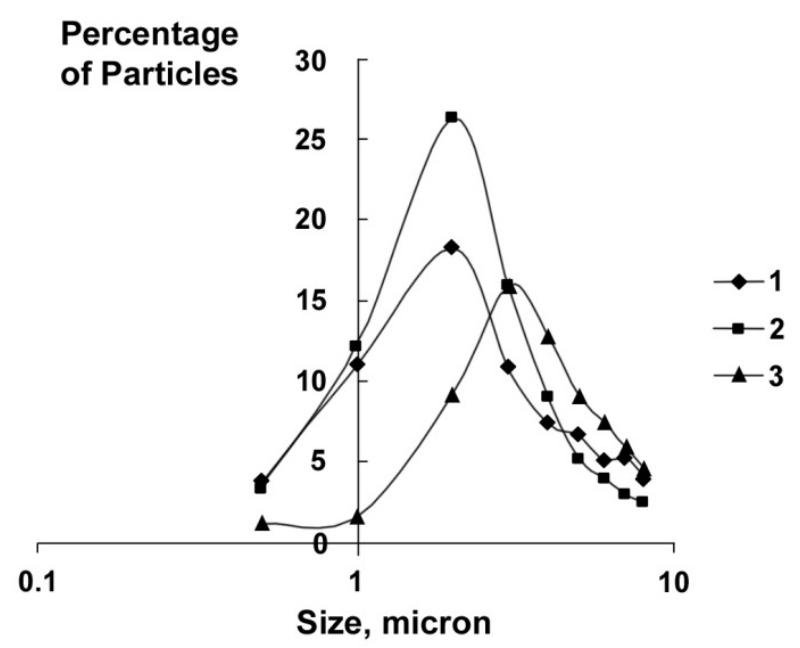

Fig. 3. Differential particle size distributions for an mixed aluminum iron oxide: ( 1 ) unmodified, (2) modified with $0.004 \mathrm{~mol} \% \mathrm{ZrO}_{2}$, (3) modified with $0.008 \mathrm{~mol} \% \mathrm{ZrO}_{2}$

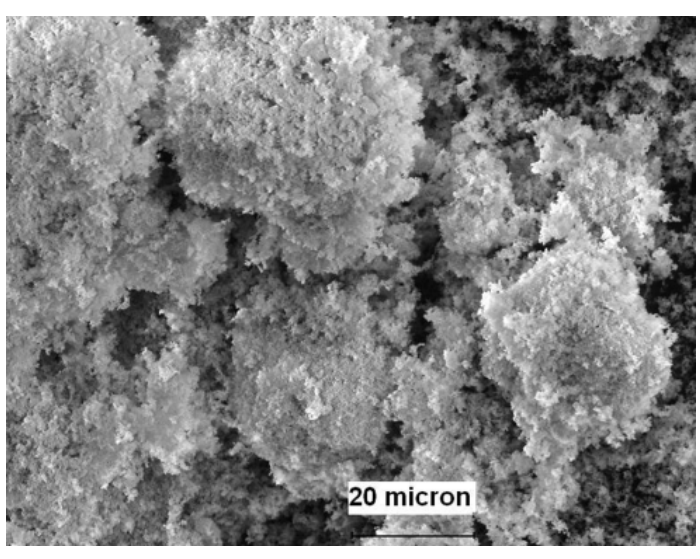

$a$

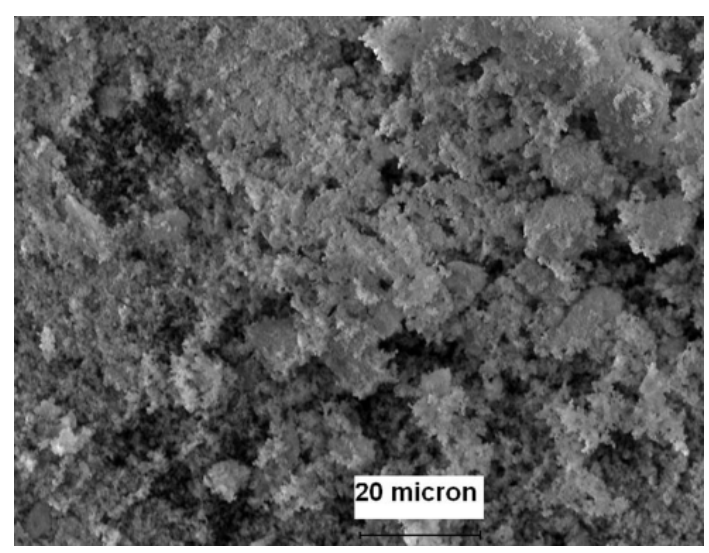

$b$

Fig. 4. SEM-micrograph of abrasive material based on a complex oxide of aluminum and iron modified with zirconium dioxide: $a$ ) with $\left.0.004 \mathrm{~mol} \% \mathrm{ZrO}_{2} ; b\right)$ modified with $0.008 \mathrm{~mol} \% \mathrm{ZrO}_{2}$

The investigation into the process of polishing of titanium by zirconia-modified complex aluminum-iron oxides (a solid solution of aluminum-iron oxides) has resulted in the following regularities. Zirconia-modified complex aluminum-iron oxides derived from hydroxycarbonate complexes exhibit high polishability in the final polishing of titanium and its alloys and offer a surface roughness $R_{a}$ of 0.009 to $0.019 \mu \mathrm{m}$, this being attributed both to enhanced tribochemical activity of abrasive particles and to increased abrasive material hardness in relation to the unmodified complex oxide.

Figure 5 demonstrates the kinetics of the changes in the polishability of the abrasive material based on solid solutions of aluminum-iron oxides when used for titanium polishing. Modification with zirconium dioxide increases polishability by a factor of 3 to 4.5 (curves 2 and 3). The initial surface roughness $R_{a}$ was 1.29 to $1.63 \mu \mathrm{m}$, the applied contact pressure was $18 \mathrm{kPa}$, the rate of sample rotation being $89 \mathrm{rpm}$. The contact pressure is one-fifth that for the known data on polishing with corundum [19]. 


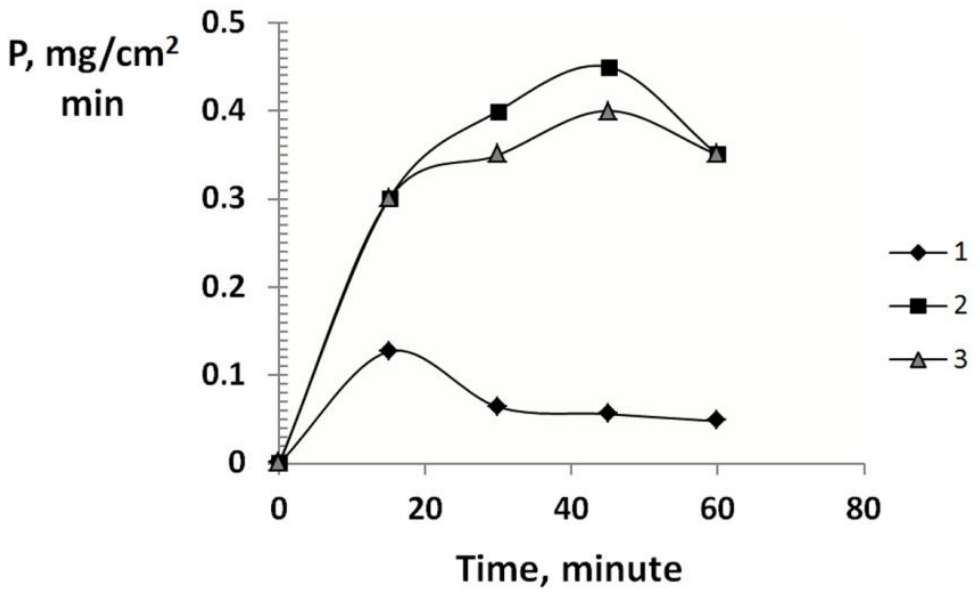

Fig. 5. Kinetic curves for polishing titanium $\left(\mathrm{P}, \mathrm{mg} / \mathrm{cm}^{2} \mathrm{~min}\right)$ by zirconia-modified $\mathrm{Al}_{2-x} \mathrm{Fe}_{x} \mathrm{O}_{3}$ solid solutions: 1 - unmodified; 2 - with 0.008 mol \% $\mathrm{ZrO}_{2} ; 3$ - with $0.004 \mathrm{~mol} \mathrm{\%} \mathrm{ZrO}_{2}$. The experimental results have been processed by methods of mathematical statistics.

The increase of contact pressure to $30 \mathrm{kPa}$ during polishing results in the plastic deformation of the titanium surface, deep stripes are observed. The zirconium dioxide concentration can be varied, namely, the concentration of $0.08 \mathrm{~mol} \% \mathrm{ZrO}_{2}$ is preferable within the first 15 to $30 \mathrm{~min}$, and then follows $0.04 \mathrm{~mol} \%$, since the process of polishing accelerates due to a change in the hardness of the abrasive material.

Final polishing with complex oxides is based on the oxidation of the metal surface. An alteration of the electron subsystem, for instance, for titanium, occurs: oxidation $\mathrm{Ti}^{\mathrm{O}} \rightarrow \mathrm{Ti}^{2+} \rightarrow \mathrm{Ti}^{4+}$. The electron spin changes in the partially occupied sublevel can be presented as follows: $3 \mathrm{~d}^{2} 4 \mathrm{~s}^{2} \rightarrow$ $3 \mathrm{~d}^{2} 4 \mathrm{~s}^{\mathrm{o}} \rightarrow 3 \mathrm{~d}^{1} 4 \mathrm{~s}^{\mathrm{o}} \rightarrow 3 \mathrm{~d}^{\circ} 4 \mathrm{~s}^{0}$. As a result, under friction in the presence of chemically active abrasive material and environment, there occurs nearly instant oxidation of the surface layer and the formation of an oxide film, which is destroyed and removed from the surface. The highest degree of oxidation is possible at contact points where microcracks are generated. As a result of oxidation and film destruction and removal, the surface is smoothened. At the initial polishing stage, as a result of the chemical action of paste components and the mechanical action of abrasive particles, oxides are formed in subsurface layer; for example, they can change into oxides as follows:

$$
\mathrm{Ti}+\mathrm{O}_{2} \rightarrow \mathrm{TiO} \rightarrow \mathrm{Ti}_{3} \mathrm{O}_{5} \rightarrow \mathrm{Ti}_{2} \mathrm{O}_{3} \rightarrow \mathrm{TiO}_{2}
$$

If mechanochemical polishing is a process occurring at the interface between solids (including the oxidation and formation of an oxide phase in the subsurface layer), then the overall system can reasonably be considered a two-phase system with a separating surface and ion exchange. Such processes are identified as heterogeneous topochemical; their kinetic regularities can be described by the Erofeev-Kolmogorov-Avrami equation found in [38]:

$$
\begin{gathered}
\alpha=1-e^{-k t^{n}}, \\
K_{o r}=n k^{1 / n},
\end{gathered}
$$

where $\alpha$ is the degree of transformation of metal atoms to oxides, which is defined as the relative intensity of metal removal $\mathrm{Ci} / \mathrm{Cmax}$ (it is assumed a priori that the factor of the mechanochemical action of the abrasive is the main one), $n$ is the number of consecutive stages during the formation of the center of the new oxide phase, $k$ is the process constant, $t$ is the duration of polishing, and $K_{o r}$ 
is the constant of the oxidation rate. These equations have been used successfully to describe the kinetics of polishing ShKh-15 steel with the participation of the reactions in the surface layer [39, 40]. As a result of studying the kinetic regularities of polishing with the use of equations (14) and (15), experimental values of $n, k$, and $K_{o r}$ for polishing titanium are obtained: $n=0.78 ; k=0.10$; $K_{o r}=0.05$ with standard deviation $S^{2}=0.005$. Figure 6 shows the kinetic curves depicting surface roughness behavior during the polishing of VT1-00 titanium samples with different abrasives. These results have been obtained with the use of an optical profilometer. For comparison, curve (1) shows the behavior of titanium surface roughness for polishing with unmodified solid solution of aluminum-iron oxides. It is obvious that $R_{a}$ achieved within $45 \mathrm{~min}$ of polishing is $0.19 \mu \mathrm{m}$, whereas the modification of solid solutions of aluminum-iron oxides with zirconium dioxide enables one to achieve 0.019-0.009 $\mu \mathrm{m}$ within the same time (curve 3). The graphics are in the logarithmic units.

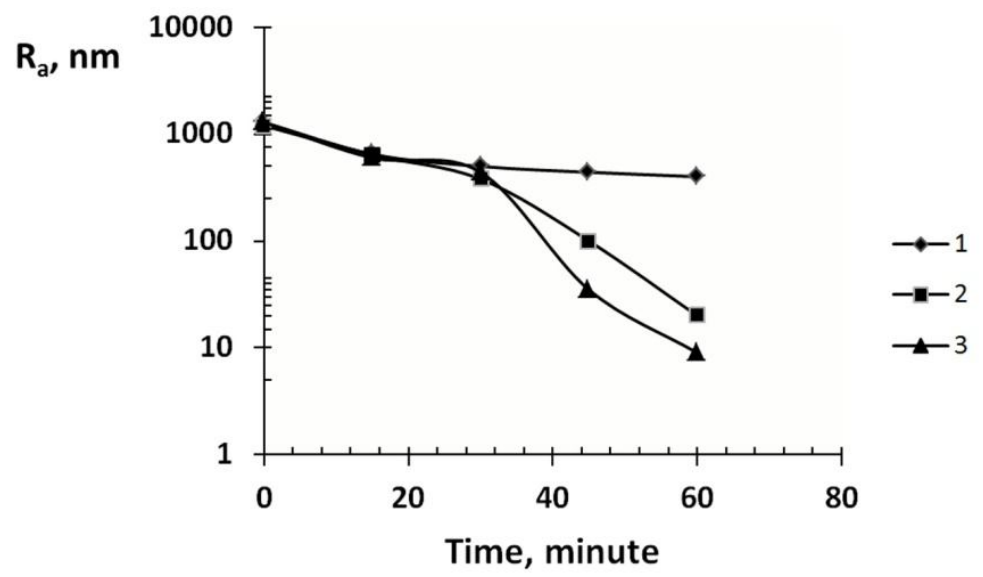

Fig. 6. Kinetic curves for the behavior of surface roughness $\mathrm{R}_{\mathrm{a}}$ upon the polishing of titanium samples: $1-\mathrm{Al}_{2-x} \mathrm{Fe}_{x} \mathrm{O}_{3}$ solid solutions; 2 - by zirconia-modified $\mathrm{Al}_{2-x} \mathrm{Fe}_{x} \mathrm{O}_{3}$ solid solutions with $0.008 \mathrm{~mol} \% \mathrm{ZrO}_{2} ; 3$ - with $0.004 \mathrm{~mol} \% \mathrm{ZrO}_{2}$.

Figure 7 illustrates the polishing effect on the surface topography of titanium samples: $a-$ initial surface roughness, $R_{a}=1.3-1.6 \mu \mathrm{m}$ (when the surface texture is rough, the surface area is chosen to be $0.9 \times 12 \mathrm{~mm}) ; b$ - typical images of the surface topography of titanium specimens polished within 60 minutes, $R_{a}=0.019 \mu \mathrm{m}\left(R_{a} 19.04 \mathrm{~nm}\right.$, sampling $\left.161.85 \mathrm{~nm}, \mathrm{~S}^{2} 1.51\right)$. According to the AFM results, $R_{a}=0.009 \mu \mathrm{m}\left(R_{a} 9 \mathrm{~nm}\right)$. $\mathrm{S}^{2}$ is equal to 1.51 when $n=5$. As a result of these definitions, the interval $R_{a}=0.009-0.019 \mu \mathrm{m}$ was selected.

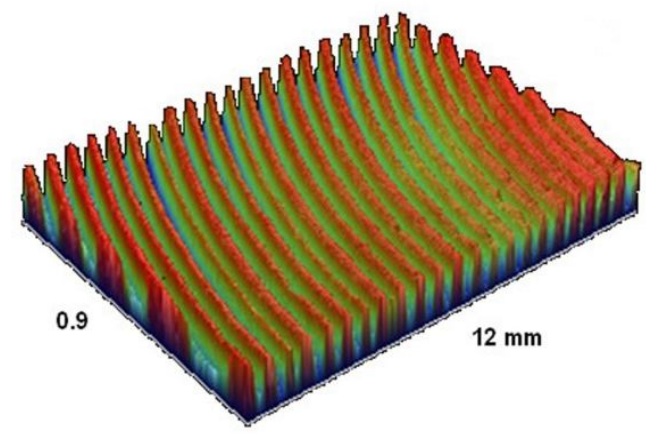

$a$

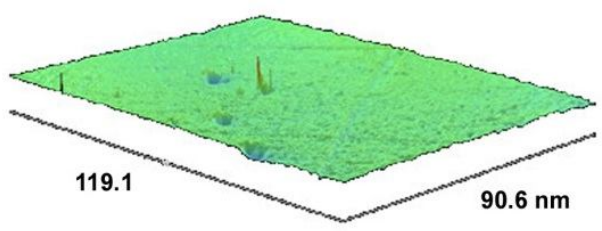

$b$

Fig. 7. The polishing effect on the surface topography of titanium specimens: $a$ - initial surface roughness, $R_{a}=1.3-1.6 \mu \mathrm{m} ; b$-typical images of the surface topography of titanium samples polished within $60 \mathrm{~min}, R_{a}=0.019 \mu \mathrm{m}\left(R_{a} 19.04 \mathrm{~nm}\right.$, sampling $\left.161.85 \mathrm{~nm}, \mathrm{~S}^{2} 1.51\right)$. 
The attainment of high-grade surface processing is attributable to the use of zirconiamodified $\mathrm{Al}_{2-x} \mathrm{Fe}_{x} \mathrm{O}_{3}$ solid solutions with a nanoparticulate particle size offering a high tribochemical material activity in polishing processes.

\section{Conclusion}

The effect of zirconium dioxide on the formation of $\mathrm{Al}_{2-x} \mathrm{Fe}_{x} \mathrm{O}_{3}$ solid solutions during heat treatment of ammonium hydroxycarbonate complexes, $\mathrm{NH}_{4} \mathrm{FeAl}_{2}(\mathrm{OH})_{5}\left(\mathrm{CO}_{3}\right)_{2} \quad n \mathrm{H}_{2} \mathrm{O}$ has been studied by XRD, IR spectroscopy, DTA, electron microscopy, and particle-size analysis. The nanoparticles have been shown to be constituted from crystalline rhombohedral $\alpha-\mathrm{Al}_{2-x} \mathrm{Fe}_{x} \mathrm{O}_{3}$, monoclinic and tetragonal $\mathrm{ZrO}_{2}\left(\mathrm{M}-\mathrm{ZrO}_{2}\right.$ and $\left.\mathrm{T}-\mathrm{ZrO}_{2}\right)$. The synthesized mixed oxide offers a high polishability, namely, 3 to 4.5 times as high as the unmodified oxide. For titanium polishing, the surface roughness $R_{a}$ reaches the interval $0.019-0.009 \mu \mathrm{m}$.

\section{Acknowledgement}

The author wishes to express her appreciation and gratitude to Ph.D. A. P. Tyutyunnik, leading research scientist at the Institute of Solid State Chemistry, of the Russian Academy of Sciences, Ural Branch for the XRD analysis of the samples.

In the experiment the Devices of the Center of Collective Use (CCU) Institute of Engineering Science of the Russian Academy of Sciences, Ural Branch, were used.

\section{References}

1. Jackson M.J., Mills B., Hitchiner. M.P. Controlled Wear of Vitrified Abrasive Materials for Precision Grinding Applications. Sadhana, 2003, vol. 28, pp. 897-914.

2. Givi M., Tehrani A.F., Mohammadi A. Polishing of the aluminum sheets with magnetic abrasive finishing method.m Int. J. Adv. Manuf. Technol., 2012, vol. 61, pp. 989-998. ISSN 0268-3768.

3. Artemov A.S. Polishing Nanodiamonds. Physics of the Solid State, 2004, vol. 46, pp. 687-695. ISSN: 1063-7834.

4. Bakharev V.P. Dispersion of Ceramics and Composites in Diamond Finishing by Free Abrasive. Russian Engineering Research, 2009, vol. 29, pp. 162-168. ISSN 1068-798X.

5. Filatova Yu.D., Yashchuk V.P., Filatov A.Yu., Heisel U., Storchak M., Monteil G. Assessment of Surface Roughness and Reflectance of Nonmetallic. Products upon Diamond Abrasive Finishing. Journal of Superhard Materials, 2009, vol. 31, no. 5, pp. 338-346. ISSN: 1063-4576.

6. Storozhenko P.A., Guseinov Sh.L., Malashin S.I. Nanodispersed Powders: Synthesis, Methods and Practical Applications. Nanotechnol. Russia, 2009, vol. 4, pp. 262-274. ISSN 1995-0780.

7. Pokropivnyi V.V., Silenko P.M. Silicon Carbide Nanotubes and Nanotubular Fibers: Synthesis, Stability, Structure and Classification. Theor. Exp. Chem., 2006, vol. 42, pp. 3-15. DOI 0040-5760/06/4201-0003.

8. Khanra A.K. Production of Boron Carbide Powder by Carbothermal Synthesis of Gel Material. Bull. Mater. Sci., 2007, vol. 30, pp. 93-96.

9. Bogdanov S.P. Influence of Superstoichiometric Boron on the Synthesis of Cubic Boron Nitride. Glass Phys. Chem., 2008, vol. 34, pp. 336-339. ISSN 1087-6596.

10. Song X.-1., Qu P., Yang H.-P., He X., Qiu G.- Z. Synthesis of $\gamma-\mathrm{Al}_{2} \mathrm{O}_{3}$ Nanoparticles by Chemical Precipitation Method. J. Cent. South Univ. Technol., 2005, vol. 12, pp. 536-541. ID: 1005 - 9784(2005)05 - 0536 - 06.

11. Garshin A.P., Gropyanov V.M., Lagunov Yu.V. Abrazivnye materialy [Abrasive Materials]. Leningrad, Mashinostroenie Publ., 1983, 230 p. (In Russian).

12. Viktorov V.V., Fotiev A.A., Badich V.D. Abrasive and Thermal Properties of $\mathrm{Al}_{2} \mathrm{O}_{3}-\mathrm{Cr}_{2} \mathrm{O}_{3}$ Solid Solutions. Inorg. Mater., 1996, vol. 32, no 55, pp. 55-57 ISSN 0020-1685. 
13. Chekhomova L.F. Abrasive Properties of Modified Chromia. Inorg. Mater., 2001, vol. 37, p. 274. ISSN 0020-1685.

14. Koroleva L.F. Modifitsyrovannye oksidy, oksogidroksid, shpineli khroma, dlya abrazivnykh $i$ pigmentnykh materialov [Modified Oxides, Oxyhydroxide, Chromium Spinels for Abrasive and Pigmentary Materials]. Ekaterinburg, UrO RAN Publ., 2002, 217 p. ISBN 5-7691-1236-0.

15. Rogov V.V., Rublev N.D., Krotenko T.L., Troyan A.V. A Study of Intensity of Tribochemical Contact Interaction between a Polishing Compound and Sapphire in Machining. Sverkhtverd. Mater., 2008, no. 4, pp. 75-78. (In Russian).

16. Koroleva L.F.. Abrasive Properties of Aluminum Iron Oxide Nanoparticles. Inorg. Mater., 2009, vol. 45, p. 1158. ISSN 0020-1685.

17. Koroleva L.F. Synthesis and Abrasive Properties of Nanoparticulate $\mathrm{MoO}_{2}-$ Modified $\mathrm{Al}_{2}-\mathrm{xFe}_{\mathrm{x}} \mathrm{O}_{3}$ and $\mathrm{Fe}_{2}-\mathrm{yAl}_{\mathrm{y}} \mathrm{O}_{3}$ Solid Solutions. Inorg. Mater., 2010, vol. 46, p. 1330. ISSN 0020-1685.

18. Dogadkina E.V., Dontsov M.G., Parfenyuk V.I. Chem. Polishing of titanium. Izv.Vuzov, Ser. Khimiya. Khim. Tekhnol., 2011, vol. 54, no 3, pp. 65-68. (In Russian).

19. Kim J., Lim E., Jung Y. Determination of efficient superfinishing conditions for mirror surface finishing of titanium. J. Cent. South Univ., 2012, vol. 19, pp. 155-162. ISSN: 2095-2899.

20. Koroleva L.F. Final Polishing of Metals to Obtain Nanoroughened Surface with nanoparticulate complex oxides of aluminum and iron. Chapter 6. In Book: Recent Advances in Abrasives Research P.286, Ed. Prof. Dirk Bähre. Nova Science Publishers. 2013, pp.173-211. ISBN: 978-1-62808-566-2.

21. Andryushchenko L.A., Grinev B.V., Tarasov V.A. Influence of the Surface State of Inorganic Scintillation Materials on Their Performance Characteristics (Review). Instruments and Experimental Techniques, 2011, vol. 54, no. 5, pp. 603-631. ISSN 0020-4412.

22. Safronov A.P., Kalinina E.G., Blagodetelev D.A., Kotov Yu.A. Separation of Aluminum Oxide Powders with Different Degrees of Aggregation by Sedimentation in an Aqueous Medium. Nanotechnol. Russia, 2010, vol. 5, p. 498. ISSN 1995-0780.

23. Belousov V.M., Chertov V.M., Rozhkova E.V., Litvin V.I., Zazhigalov V.A. A Sol-Gel Method for Synthesizing Porous Iron-Aluminum Oxide Substances and Regulation of their Physicochemical Characteristics. Theoretical and Experimental Chemistry, 1997, vol. 33, pp. 120-123. ISSN: 0040-5760.

24. Silyakov L., Pesotskaya N.S., Yukhvid V.I. Selfpropagated High-Temperature Synthesis and Properties of Corundum-Based Abrasive Composition Material. Inorg. Mater.,1995, vol. 31, pp. 351-357. ISSN 0020-1685.

25. Tarasov A.G., Gorshkov V.A., Yukhvid V.I. Phase Composition and Microstructure of $\mathrm{Al}_{2} \mathrm{O}_{3}-\mathrm{Cr}_{2} \mathrm{O}_{3}$ Solid Solutions Prepared by Self-Propagating High-Temperature Synthesis. Inorg. Mater., 2007, vol. 43, p. 724. ISSN 0020-1685.

26. Merzhanov A.G., Borovinskaya I.P. Historical Retrospective of SHS: An Autoreview. International Journal of Self-Propagating High-Temperature Synthesis, 2008, vol. 17, no. 4, pp. 242-265. ISSN 1061-3862.

27. Romanova R.G., Petrova E.V. Phase Composition of Aluminum-Zirconium Oxide Nanocrystals Prepared by Electrochemical Coprecipitation. Russian Journal of Physical Chemistry, 2006, vol. 80, no. 6, pp. 974-979. ISSN 0036-0244.

28. Isasi-Marín J., Pérez-Estébanez M., Díaz-Guerra C., Castillo J.F., Correcher V., Cuervo-Rodríguez M.R. Structural, magnetic and luminescent characteristics of $\mathrm{Pr}^{3+}$-doped $\mathrm{ZrO}_{2}$ powders synthesized by a sol-gel method. Journal of Physics D: Applied Physics, 2009, vol. 42, no. 7. DOI: 10.1088/0022-3727/42/7/075418.

29. Isasi J., Perez M., Castillo J.F., Correcher V., Aldama I., Arevalo P., Carbajo M.C. Preparation and characterization of $\mathrm{Ce}_{0.95} \mathrm{Zr}_{0.05} \mathrm{O}_{2}$ nanopowders obtained by sol-gel and template methods. Materials Chemistry and Physics, 2012, vol. 136, no. 1, pp. 160-166. DOI: 10.1016/j.matchemphys.2012.06.046. 
30. Panova T.I., Morozova L.V., Drozdova I.A., Shilova O.A. Sol-Gel Synthesis of Solid Solutions Based on Zirconium and Hafnium Dioxides. Glass Physics and Chemistry, 2011, vol. 37, no. 5, pp. 505-511. ISSN 1087-6596.

31. Kuznetsov P.N., Zhizhaev A.M., Kuznetsova L.I. Mechanochemical Synthesis of Nanosize Metastable Zirconium Oxide. Russian Journal of Applied Chemistry, 2002, vol. 75, no. 2, pp. 171-176. ISSN: 1070-4272.

32. $\mathrm{Xu}$ X., Wang X. Fine Tuning of the Sizes and Phases of $\mathrm{ZrO}_{2}$ Nanocrystals. Nano Res., 2009, vol. 2, pp. 891-902. ISSN: 1998-0124.

33. Koroleva L.F. Teoriya i praktika gazovogo analiza [Theory and Practice of Gas Analysis], Ekaterinburg: Ural State Forest Engineering University Publ., 2002, 153 p. (In Russian).

34. Koroleva (Chekhomova) L.F. Synthesis of Spinel-Based Ceramic Pigments from Hydroxycarbonates. Glass Ceram., 2004, vol. 61, no. 9-10, pp. 299-302. ISSN: 0361-7610.

35. Chekhomova L.F., Cherednichenko N.V. Zirconium Phosphate as an Ion-Exchanger for the Separation of Samarium and Neodymium. J. Anal. Chem., 1998, vol. 53, no. 10, pp. 897-901. DOI 1061-9348/98/5310-0897.

36. Gutzov S., Peneva S.K. Formation of the monoclinic zirconia phase by heating from hydrous zirconium oxide. Journal of Materials of Science Letters, 1998, vol. 17, pp. 1535-1537. ISSN: 0261-8028.

37. Toropov N.A., Barzakovskii V.P., Lapin V.V., Kurtseva N.N. Diagrammy sostoyaniya silikatnykh sistem: spravochnik. Vyp. pervyi. Dvoinye sistemy. [State Diagrams of Silicate Glasses, Issue 1: Binary Systems]. Leningrad: Nauka,1969, p. 822.(In Russian).

38. Boldyrev V.V. Reaktsionnaya sposobnost tverdykh tel [Reaction Ability of Solids]. Novosibirsk, Sib. Branch RAN, 1997, 303 p. (in Russian).

39. Koroleva L.F. Final Polishing of Metals to Obtain Nanoroughened Surface. Nanotechnologies in Russia, 2012, vol. 7, no. 1-2, pp. 67-75. ISSN 1995-0780

40. Koroleva L.F. Tribochemical Activity of Mixed Oxides of Abrasive Materials in Metal

Polishing. Fiz. Khim. Obrab. Mater., 2006, no. 4, pp. 84-92. (In Russian). 